\title{
Outcome of Pregnancies Among Sickle Cell Patients Admitted to Cotonou University Hospitals (Benin) from 2008 to 2018
}

\author{
Dangbemey Djima Patrice*, Tognifode Veronique, Azonbakin Simon, Tchiakpe-Enialoko Nicole, \\ Aboubakar Moufalilou, Ogoudjobi Mathieu, Lokossou Symphorose, Nzikou Venance, \\ Tshabu-Aguemon Christiane, Hounkpatin Benjamin, Tonato-Bagnan Josiane, Denakpo Lewis
}

Faculty of Health Sciences, University of Abomey-Calavi, Cotonou, Benin

\section{Email address:}

ddpatous78@yahoo.fr (D. D. Patrice), Verofode@yahoo.fr (T. Veronique), Azandeg@yahoo.fr (A. Simon)

${ }^{*}$ Corresponding author

\section{To cite this article:}

Dangbemey Djima Patrice, Tognifode Veronique, Azonbakin Simon, Tchiakpe-Enialoko Nicole, Aboubakar Moufalilou, Ogoudjobi Mathieu, Lokossou Symphorose, Nzikou Venance, Tshabu-Aguemon Christiane, Hounkpatin Benjamin, Tonato-Bagnan Josiane, Denakpo Lewis. Outcome of Pregnancies Among Sickle Cell Patients Admitted to Cotonou University Hospitals (Benin) from 2008 to 2018. Journal of Gynecology and Obstetrics. Vol. 8, No. 6, 2020, pp. 154-160. doi: 10.11648/j.jgo.20200806.11

Received: September 4, 2020; Accepted: September 21, 2020; Published: October 30, 2020

\begin{abstract}
Objective: Study the fetal-maternal and neonantal prognosis of sickle cell pregnancies managed in Cotonou's hospitals (R. Benin). Material and methods: This is a descriptive study on retrospective data from January 2008 to December 2018. The maternities of the Lagoon Mother and Child Hospital and University (CHU-MEL) center and of the CNHU/HKM gynecology and obstetrics university clinic had served as a framework. Complete patients records were analyzed. Included were pregnant women or delivered at 28 weeks of amenorrhea (AW) or beyond, sickle cell disease SS or SC confirmed by hemoglobin electrophoresis. Sociodemographic, clinical, therapeutic, and fetal-maternal and neonatal prognosis were analyzed. EPI DATA 3.1 and SPSS 2.0 software were used to analyze our data. The difference is significant for a $p$-value $\leq 5 \%$. Ethical and professional standards and rules were respected. Results: The delivery of a patient suffering from sickle cell disease represented $0.82 \%$ of births. The SS phenotype was observed in $27.3 \%(n=105)$ versus $72.7 \%(n=279)$ of SC (p=0.000). A history of obstetric complications was noted in $56.8 \%(n=218)$. The course of the current pregnancy was marked by obstetric complications in $97.4 \%$ and the most important were: the threat of premature delivery (28\%) and the vaso-occlusive crisis (19.5\%). The caesarean was performed in $92 \%$ of sickle cell patients. Premature delivery was observed in $60 \%$ with $6.3 \%$ very premature $(28-33 \mathrm{AW})$. It was registered $91 \%(\mathrm{n}=352)$ live births, 48\% $(\mathrm{n}=169)$ hypotrophs, 60\% premature, $1.1 \%(\mathrm{n}=4)$ intrapartum deaths and $8 \%(n=4)$ intrapartum deaths and $8 \%(n=31)$ deaths in utero. Perinatal mortality represented $9 \%$. The after-effects of childbirth were complicated in $12 \%(n=46)$. The puerperal infections $(32.6 \%)$, hypertension $(28.2 \%)$ and its complications and severe anemia (19.2\%) were the most common complications. Five (5) maternal deaths were deplored, ie a mortality rate of 1420 maternal deaths per 100,000 live births. Conclusion: In Benin, pregnancy and delivery of sickle cell disease are at high risk of fetal, maternal and neonatal mortality. Caesarean section was almost routine in this group. The practice of transfusion exchange or bleeding may improve prognosis.
\end{abstract}

Keywords: Pregnancy, Sickle Cell Disease, Mortality, Benin

\section{Introduction}

Sickle cell disease is a genetic, self-assisted self-assistive of the hemoglobin structure characterized by replacing glutamic acid by valine in position $n^{\circ} 6 \beta-1$ channel of globin, which results in the synthesis of an abnormal hemoglobin
«HB S». The altered protein causes a deformity of the red blood cell causing many complications. [1] Because of the incalming of hemoglobin, these patientsare at risk of several complications such as hemolytic anemia, thrombotic risk, the risk of injection and occlusive vaso crisis. [2, 3] In Benin, homozygotic forms SS and heterozygous $\mathrm{SC}$, responsible for 
sickle cell syndromes, are the most common [4] Any pregnancy on sickle cell soil is therefore a risky pregnancy. Strict, multidisciplinary follow-up involving the obstetrician, the hematologist and the reinimoring is necessary in the light of recommendations [5]. But this organizational and technical arsenal is still not available in the Benin National Reference Centers where most of the sickle cell pregnant women are referred for a mulguous support. To this context must be added the disparity in the provision of antenatal care in general and especially to this specific group. According to the fifth population of Health Demographic Survey of Benin (EDSBV) maternal health indicators show poor coverage in antenatal care in 2018. Women who have completed four prenatal and more expensive $55 \%$ at the national level [6]. The objective was to describe the maternal and neonatal prognosis of these pregnancies and compare them with the litterature data.

\section{Patients et Methods}

This is a descriptive study on retrospective data covering a period of 10 years from January 2008 to December 2018. It took place over 8 months (January to September 2019) in the reference maternities of the Lagoon Mother and Child Hospital and University Center (CHU MEL) and the University Clinic of Gynecology and Obstetrics (CUGO) of CNHU/HKM. The complete records studied were those of deliveries at 28 weeks of complete amenorrhea (WA), sickle cell disease SS or SC confirmed by hemoglobin electrophoresis. The files of newborns from these mothers with sickle cell disease were analyzed. The sampling was non-probability. All files meeting the selection criteria have been identified. The variables studied were sociodemographic (age, origin, occupation, level of education), history (medical and obstetric), data from prenatal follow-up, childbirth and immediate childbirth. Term at birth, APGAR score, birth weight, and early neonatal complications were variables related to newborns. The information collected as part of this study was treated anonymously. This study, carried out within the framework of academic work, was conducted in strict compliance with the rules of good clinical practice (GCP). The data processing was done by Epi data 3.1 software for the input mask and SPSS20 software for data analysis. The difference is significant for a p-value of $5 \%$.

\section{Results}

\subsection{Epidemiological Aspects}

During the study period, the two maternities recorded 816 deliveries to mothers with sickle cell disease out of a total of 99,468 deliveries, ie a frequency of $0.82 \%$. For archiving and file keeping reasons and given the inclusion criteria, only 384 eligible files were retained for this study. The SS hemoglobin phenotype was observed in $27.3 \%(\mathrm{n}=105)$ versus $72.7 \%$ $(\mathrm{n}=279)$ for the SC phenotype $(\mathrm{p}=0.0000)$. The average age was $24 \pm 2,97$ years. Teenage girls (10-24years) accounted for
$37.7 \%(n=145)$. The vast majority of sickle cell deliveries (96\%) had jobs with precarious monthly income. They had at least the primary level in $68.3 \%$ of cases (Table 1 ).

Table 1. Socio-demographic characteristics of sickle cell patients.

\begin{tabular}{lll}
\hline Socio-demographic characteristics & Effective (n) & Percentage (\%) \\
\hline Age & & \\
$15-20$ & 18 & 4,7 \\
$20-25$ & 127 & 33 \\
$25-30$ & 161 & 41,9 \\
$30-35$ & 53 & 13,8 \\
$\geq 35$ & 25 & 6,5 \\
Total & 384 & 100 \\
Occupation & & \\
Housewife & 124 & 32,3 \\
Farmer & 54 & 14 \\
Seller & 153 & 39,8 \\
Official & 16 & 4,2 \\
Female worker/Craftswoman & 23 & 5,9 \\
Student/University student & 14 & 3,6 \\
Total & 384 & 100 \\
Educational level & & \\
Uneducated & 122 & 31,8 \\
Primary school & 190 & 49,4 \\
Secondary school & 49 & 12,8 \\
University & 23 & 600 \\
Total & 384 & \\
\hline
\end{tabular}

\subsection{Clinical Aspects}

Of the 384 patients, $119(30.9 \%)$ had major sickle cell syndromes as a history. Vaso occlusive crisis were the most frequent and observed in $58 \%$ of the deliveries $(n=69)$. The majority $(72.6 \%)$ of patients $(n=279)$ were nulliparous or pauciparous. (Table 2)

Table 2. Distribution according to sickle cell phenotypes and its complications.

\begin{tabular}{lll}
\hline Characteristics & Effective (n) & Percentage (\%) \\
\hline Phenotype & & \\
SS & 105 & 27,3 \\
SC & 279 & 72,7 \\
Total & 384 & 100 \\
Complications outside pregnancy & & \\
Vaso-occlusive crisis & 69 & 18 \\
Cardiac & 2 & 0,52 \\
Hepatic & 3 & 0,78 \\
Bone & 3 & 0,78 \\
Cutaneous & 3 & 0,78 \\
Severe anemia with blood exchange & 39 & 10,1 \\
No complication & 264 & 68,7 \\
Total & 384 & 100 \\
\hline
\end{tabular}

No history of obstetric complications was recorded in $43.3 \%$ $(\mathrm{n}=166)$. In contrast, 218 patients $(56.8 \%)$ had developed obstetric complications in previous pregnancies. A history of premature childbirth was observed in $32.1 \%$, vasculo-renal syndromes in $19.3 \%$ and anemia $(18.3 \%)$ having required blood transfusion in the past. (Table 3 ) 
Table 3. Distribution of births based on obstetric history.

\begin{tabular}{lll}
\hline Obstetric history & Effective (n) & Percentage (\%) \\
\hline Parity & & \\
Nulliparous (00) & 151 & 39,3 \\
Pauciparous (1-3) & 128 & 33,3 \\
Multiparous (4-5) & 77 & 20 \\
Large multiparous $(\geq 6)$ & 28 & 7,3 \\
Total & 384 & 100 \\
\hline
\end{tabular}

Prenatal follow-up of the current pregnancy in terms of frequency was normal for $66.9 \%$ of pregnant women $(n=257)$. It was not optimal for $24.4 \%(n=94)$. The total absence of prenatal follow-up was observed in $8.6 \%(n=33)$. With regard to the quality of the staff provided $10.3 \%$ surveillance $(n=36)$. A multidisciplinary team made up of midwife, obstetrician and hematologist provided prenatal monitoring for $49.8 \%(n=175)$. No pregnant woman with sickle cell disease had benefited from transfusion exchange or bleeding in our series. Only $2.6 \%(\mathrm{n}=10)$ had experienced no complications throughout the course of the current pregnancy. Most (97.4\%; $\mathrm{n}=374)$ had developed obstetric complications such as the threat of preterm labor (28\%) major sickle cell syndrome with vaso occlusive crisis type in (19.5\%), vasculo-renal $(6.8 \%)$, intrauterine growth retardation $(0.78 \%)$, malaria $(11.5 \%)$, urinary tract $(11.5 \%)$, severe anemia (12.5\%) death in utero (8\%). (Table 4)

Table 4. Distribution according to obstetric complications on pregnancy currently.

\begin{tabular}{lll}
\hline $\begin{array}{l}\text { Obstetric complications on } \\
\text { pregnancy currently }\end{array}$ & Effective (n) & Percentage (\%) \\
\hline Threat of premature labor & 105 & 27,3 \\
Vasculo-renal syndrome & 26 & 06,8 \\
Intrauterine growth retardation & 3 & 0,78 \\
Malaria & 44 & 11,5 \\
Urinary infection & 44 & 11,5 \\
Severe anemia $(\leq 6 \mathrm{~g} / \mathrm{dl})$ & 48 & 12,5 \\
Vaso-occlusive crisis & 73 & 19 \\
In utero death & 31 & 8 \\
No complication & 10 & 02,6 \\
Total & 384 & 100 \\
\hline
\end{tabular}

\subsection{Delivery}

The vaginal delivery was observed in $8 \%(n=31)$ and by caesarean section in $92 \%(n=353)$. Prophylactic caesarean section for sickle cell was indicated $61 \%$ as shown in figure 1. The delivery was premature in $60 \%$ with $6.3 \%$ very premature (28-33 weeks).

Indications for caesarean section

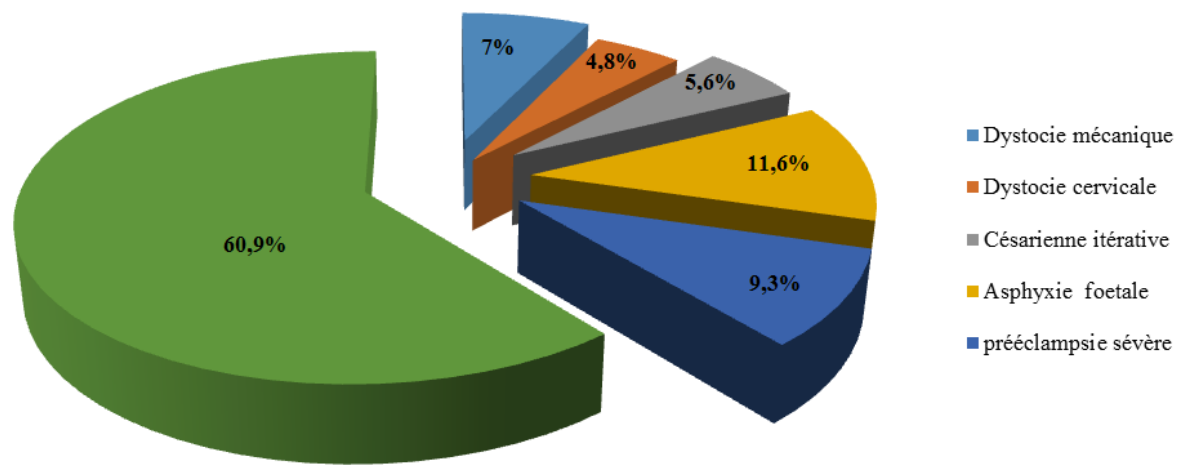

Figure 1. Distribution of Indications for Caesarean Section.

\subsection{Post Delivery and Prognosis}

Post-delivery was marked by complications in $12 \%$ of patients $(\mathrm{n}=46)$. Among these complications were puerperal infections (32.6\%), hypertension $(28.2 \%)$ and its complications and severe anemia (19.2\%). There were 5 cases of maternal death in our series. That is a mortality rate of 1,420 maternal deaths per 100,000 live births. (Table 5)

Table 5. Distribution of Childbirth According to the Evolution of Childbirth.

\begin{tabular}{lll}
\hline Evolution of childbirth & $\begin{array}{l}\text { Effective } \\
(\mathbf{n = 3 8 4})\end{array}$ & $\begin{array}{l}\text { Percentage } \\
(\mathbf{\%})\end{array}$ \\
\hline Simple childbirth & 338 & 88 \\
Complicated childbirth & 46 & 12 \\
Types of childbirth complications & $(\mathrm{n}=46)$ & \\
Vaso-occlusive crisis & 07 & 15,2 \\
Severe anemia & 09 & 19,5 \\
Hypertension and its complications & 13 & 28,2 \\
Post-partum haemorrhages & 5 & 10,8 \\
\hline
\end{tabular}

\begin{tabular}{lll}
\hline Evolution of childbirth & $\begin{array}{l}\text { Effective } \\
(\mathbf{n = 3 8 4 )}\end{array}$ & $\begin{array}{l}\text { Percentage } \\
(\mathbf{\%})\end{array}$ \\
\hline Pueraperal infection & 15 & 32,6 \\
Postoperative wall suppuration & 3 & 6,5 \\
Maternal death & 5 & 10,8 \\
Corrected maternal mortality rate & $5 \times 100.000 / 352$ & 1420 \\
\hline
\end{tabular}

All 384 patients has 1780 hospital days ie a 5-day hospital stay (DMS) with extremes ranging from 3 to 43 days.

\subsection{Neonatal Prognosis}

A total of 387 deliveries including 3 twins have been recorded. It has been recorded 352 living births (91\%), 4 intra partum fetals $(1.1 \%)$. And $31(8 \%)$ in expelled in utero deaths. Ie perinatal mortality of $9 \%$.

The delivery was premature $(<37 \mathrm{AW})$ in $58.8 \%(\mathrm{n}=226)$ of which $6.3 \%(n=24)$ of high prematurity $(28-33 \mathrm{AW})$.

Hypotrophy was recorded in $48 \%(n=169)$ of births. Fetal 
weight was less than $2500 \mathrm{~g}$ at $44.2 \%(\mathrm{n}=171)$ of which $24 \%$ weight less than $2000 \mathrm{~g}$. Neonatal morbidity other than premature and hypotrophy was observed in $31.5 \%(n=111)$.

Tables 6 show neonatal prognosis.

The adaptation to extra uterine life was poor and required intensive resuscitation in $31.1 \%$ of births $(n=106)$ at the 1 st minute and in $17.3 \%(\mathrm{n}=61)$ at the 5 th minute. Hypotrophy $(48 \%)$ and prematurity $(60 \%)$, morbidity cases accounted for $35 \%(n=124)$, and early neonatal mortality was 36 per 1000 live births. (Table 6)

Table 6. Adaptation to Ectopic Life.

\begin{tabular}{lll}
\hline Characteristics & Effective & Percentage \\
\hline APGAR 5 $^{\text {th }}$ minute & & \\
\hline$\leq 3$ & 15 & 4,3 \\
$4-7$ & 91 & 25,8 \\
$\geq 8$ & 246 & 69,8 \\
Total & 352 & 100 \\
\hline
\end{tabular}

\begin{tabular}{lll}
\hline Characteristics & Effective & Percentage \\
\hline APGAR 5th minute & & \\
\hline$\leq 3$ & 5 & 1,4 \\
$4-7$ & 56 & 15,9 \\
$\geq 8$ & 291 & 82,7 \\
Total & 352 & 100 \\
\hline
\end{tabular}

\section{Discussion}

Through this study, we report the socio-demographical, clinical, biological and prognosis data on a series of 384 pregnancies due to sickle cell disease from 2013 to 2017 in the reference university maternities of Cotonou in Benin.

\subsection{Epidemiological Data}

Sickle cell disease is the first genetic disease in black subjects; and thus in 2006, the WHO, given the high frequency of sickle cell disease in Africa, identified the continent as a public health priority in the world in terms of sickle cell disease control. [7]

Our series found a prevalence of $0.82 \%$ of pregnancy on a sickle cell anemia. Diallo DA and al. In 2018 had observed a prevalence of $1.3 \%$ in Bamako slightly higher compared to our result. [8]. In Cameroon in 2019, the prevalence of pregnancy for sickle cell disease was $0.1 \%$. [9] Patel S. and al. in 2017 observed a frequency of $4.8 \%$ of pregnancy with sickle cell disease. [7]

These prevalence were significantly higher compared to North American data which show frequencies ten times lower. Indeed, according to Kuo K. and al. in a North American series in 2016, the prevalence of pregnancy on the sickle cell disease was $0.017 \%$ [10]. In another American multicenter series in 2017, Evelyn Bae and al found a frequency of $0.2 \%$. [20] This low prevalence compared to African data and especially from Benin could be explained by the precautions taken in these developed countries for avoiding sickle cell disease. This would pass through the practice of the prenuptical examen, amniocentesis and eugenic abortions to reduce the rate of sickle cell children. These precautions are not systematic in developing countries such as Benin. It is necessary to strengthen awareness in the limitation of the birth of the sickle cell patients in Benin.

\subsection{Socio-professional Characteristics}

The average age of pregnant sickle cell women in our series was 24 \pm 2.97 (16-40). In Cameroon in 2019 Nkwabonga E. and Coll found an average age of 27.5 \pm 5.8 (18-40) [9].

Our population appears to be younger than that of the Cameroon series. Indeed, teenagers made up $37.7 \%$ of our population. This proportion is close to that reported in the Western literature by Janky E and Coll in 2006 [5]. The young age of our population could be explained by the fact of early marriages in general but in particular in the sickle cell group. Life being limited by the complications of sickle cell disease, some parents do not hesitate to encourage early marriage in the hope of somehow replacing the sickle cell pregnant woman. In Cameroon in 2019, the average age of sickle cell pregnant woman was $27.5 \pm 5.8$ (18-40).

The vast majority of the patients $(96 \%)$ had jobs with insecure monthly income, suggesting that sickle cell disease seems to be a disease of the underprivileged. This observation is made by J. B. Arlet who affirmed through his series the unfavorable economic conditions of sickle cell patients [11]. But it should be noted that we had worked on hospital series. And our country, public hospitals are first frequented by the lower class.

\subsection{Clinical Aspects}

A history of major sickle cell syndrome was observed in $30.9 \%$ ( $n=119)$. Vaso-occlusive crisis were most frequent and observed in $58 \%$ of the deliveries $(n=69)$. This result confirms that the sickle cell patient is potentially at risk of complications. Concerning morbidity, Diop S. and coll had already noted this in their series.

Of 118 patients followed in a year, $96.3 \%$ had at least one (1) transfusion and $64.8 \%$ hospitalized at least at one times in a year. Chronic complication was found in $49 \%$ of patients (53/108). [12] Candles in their majority were nulliparous $(33 \%)$ or pauciparous $(39 \%)$. Kuao K. and Coll found in their $46 \%$ series of nulliparous. The precocity of pregnancies in sickle cell patients in the quest for a less sickly descendent burden of source of family revenue coukd be the reason for a reduced number of nulliparous in our series compared to the data of Kuao study. [10]

Obstetrical complications on earlier pregnancies were observed in 56.8\% $(\mathrm{n}=218)$. Premature delivery $(32.1 \%)$, vasculo-renal syndromes $(19.3 \%)$ and anemia (18.3\%) requiring blood transfusion were the most common obstetric complications. (Table 3). Although the majority of previous pregnancies had had complications, patients were not prevented from contracting a new pregnancy. This is the importance of having a child in Africa and Benin in particular. Our results corroborate the data of Kuao K. and 
coll. According to these authors, the sickle cell patient, compared to a non-sickle cell patient has an increased risk of underlying chronic hypertension $(2.3 \%$ vs $1.1 \%$; $=0.38)$, fetal abnormalities (14.0 compared to 6.4\%; $\mathrm{P}<0.001)$, severe pre-stream, childhood premature, low birth weight. [10]

Prenatal monitoring in terms of frequency was not optimal in $24.4 \%(n=94)$ of sickle cell pregnant women greats and a total fault has been noted in $8.6 \%(n=33)$ of our series. N. Lélicée and Coll in 2013 had found 1.3\% of pregnancies not in foolow-up in their series. [13] According to the Demographic Survey of Benin Health in 2018, 48\% of the prenatal consultations were not well followed. [6]

The prenatal consultations of sickle cell pregnant women are naturally limited. It is the finding made by Kuao $\mathrm{K}$ and Coll that had found in their series in 2016 that Women with sickle cell disease were more likely to have limited prenatal care (7.4 compared to $3.8 \% ; \mathrm{P}=001)$. [10]

Prenatal monitoring was provided by unmanual workers in $10.3 \%(n=36)$ and a multidisciplinary team of midwood, obstetrecian and hematologist in $49.8 \%(n=175)$. For several years, research on sickle cell disease have concluded that the development of care programs based on strictly obstetric and hematology collaboration has significantly improved the future of these pregnancies [17] the proportion of patients who benefited from prenatal consultations performed by qualified workers was lower than the national average. Indeed, according to EDSB 2018, the percentage of women who have received prenatal care provided by a qualifed provider was $95 \%$. This difference can be explained by the fact that Cotonou's reference maternity are all III level and receive all serious cases of the inside including sickle cell disease on pregnancy. But the pregnancy rate followed by a qualified agent inside Benin turns around 65\%. [6]

No sickle cell pregnant women had benefited from exchange or bleeding. The technical tray in Benin does not allow a transfusion exchange the technique of bleeding to 22 AW should be considered. Despite the practice of bleeding in subregion, Benin does not practice it yet. Is this a training or culture problem? The implementation of a pilot feasability study and its efficiency is necessary. The hematopoietical transplantation of stem cells would be the only curative treatment of complications of sickle cell disease. [14] According to Elizabeth B. and Coll simple transfusion is recommended to address the symptomatic anemia with a 9 $\mathrm{g} / \mathrm{dL}$ hemoglobin rate. The transfusion exchange is indicated to prevent or process complications resulting from the presence of $\mathrm{Hb} \mathrm{S}$. The most importaant objectives are reduction of $\mathrm{HbS}$ while preventing hyperviscosity. [15]

The absence of this practice in our series could explain the importance of complications. Obstetric complications were observed in $97.4 \%$ of patients $(n=374)$ of these complications, premature delivery $(32.1 \%)$, vasculo-renal syndromes $(19.3 \%)$ and anemia (18.3\%) requiring blood transfusion were the most common complications.

Kuao K. and coll had found the same complications in variable proportions without specifying in the presence or not of transfusion exchange.
This included chronic hypertension, fetal abnormalities, severe preeclampsia, preterm delivery, low birth weight for gestational age, and caesarean delivery. [10]

\subsection{Delivery in Sickle Cell Disease and Prognosis}

In our series, 352 live births $(91 \%)$ of sickle cell mothers were recorded 468 live births $(73.8 \%)$ of the pregnancies in the series by Patel S. and coll. Vaginal delivery was performed in $8 \%(n=31)$ and caesarean section in $92 \%$ $(\mathrm{n}=353)$. Patel S. and coll observed an opposite distribution in India in their series where $75 \%$ of deliveries took place vaginally against $25 \%$ by caesarean section. The practice of transfusion exchange and rigorous monitoring of pregnant women improved the prognosis of natural delivery in the Pastel S. series. [16]

Premature delivery was observed in $60 \%$ with $6.3 \%$ of very prematurity (28-33 WA). The prematurity induced by sickle cell disease varies according to the series: Patel S. and coll (10\%) [17], of Montalembert M. (21\%). [17]

Prematurity was mostly induced in our series for series for sickle cell anemia by fear of death in utero from senescence of the placenta after 36 weeks. Thus, most caesarean sections (61\%) were prophylactic before term. (Figure 1) According to Kuao $\mathrm{K}$ and coll. The risk of premature delivery was multiplied to 2.5 and that of delivery by caesarean section by 1.93 with sickle cell disease. [10]

The after-effects of childbirth were marked by $12 \%$ of puerperal complications in our series. Evelyn Bae and coll. In the United States in 2017 in a large multicenter series grouping together 3 large cities, had noticed that the aftereffects of shifts in sickle cell patients were at greater risk of complications compared to non-sickle cell patients. Readmission for postpartum complications of sickle cell disease was $27 \%$ between the 30th and 90th day postpartum. Maternal postpartum morbidity in our series was linked to urinary tract infections, puerperal endometritis, hypertension and its complications, severe anemia and major sickle cell syndrome. The study by Evelyn Bae and coll. 2017 had made a complete mapping of postpartum complications in sickle cell patients, including the complications in sickle cell patients, including the complications observed in our series. [20] There have been 5 cases of maternal death for 352 live births, ie a lethality of 1,420 maternal deaths per 100,000 live births. According to EDSB 2017-2018, the maternal mortality rate was 391 per 100,000 live births. Maternal mortality, in the group of pregnant sickle cell women in Benin, was multiplied by 3.6 compared to maternal mortality in the general population. [6] Lesage N. and coll. in 2015 in France had found a lethality of 454 per 100,000 live births and $87 \%$ of maternal deaths occurred in postpartum period. [21] According to Can Boga and coll in Cameroon in 2016, maternal and fetal mortality associated with sickle cell disease ranged from $11.4 \%$ to $20 \%$. [18] According Amanda Redden Hathaway in 2016, sickle cell disease in pregnancy leads to multiple complications that put mother and fetus at risk, and patients with sickle cell disease have six times the mortality during pregnancy compared to non-sickle cell 
patients. [19] The results of our series corroborate these data from the literature showing excess maternal and neonatal mortality. Early neonatal mortality was 36 per 1000 live births in our series (Table 6) while it was estimated at 30 per thousand according to EDSB 2017-2018. [6]

Neeta Natu and coll in India in 2014 had noted five intrauterine fatal deaths and one early neonatal death in their cohort. Through this study, they confirmed the increased risk of fetal death in women with sickle cell disease. [22]

\section{Conclusion}

Almost all pregnancies associated with sickle cell disease had major obstetric complications. The threat of premature birth and occlusive vaso crisis were more common in a context where transfusion exchange or bleeding is not practiced. Routine caesarean section was the preferred delivery method for sickle cell disease between 2008 and 2018 in Cotonou. Maternal and neonatal mortality rates increased 3.6 and 1.2 times respectively in the sickle cell disease group compared to the national average in Benin.

Adequate monitoring of pregnancies associated with sickle cell disease and the exchange of transfusions or bleeding in Cotonou may improve fetal-maternal and neonatal prognosis.

\section{Declaration of Links of Interest}

The authors declare that they have no competing interest.

\section{References}

[1] C. Arnal; R Girot. Drépanocytose chez l'adulte. Encycl Méd Chir. Editions Scientifiques et Médicales. Elsevier SAS, Paris, Hématologie, 13-006-D-16, 2002; 15 p.

[2] Arnal C, Girot R. Drépanocytose chez l'adulte. Encycl Med Chir (Editions Scientifiques et Médicales Elsevier SAS, Paris, tous droit réserves).2002; 13-006-D-16, $15 \mathrm{p}$.

[3] Bourbillon. A. Pédiatrie pour le praticien 6è édition; Elsevier; Masson; 2011; p 46.

[4] Houndeffo T, Adisso S, Tshabu-Aguemon C, Rahimy Mc. Houssou F. K, De Souza J, Takpara I, Alihonou E. Issue de la grossesse chez les drépanocytaires. Journal de la Société de Biologie Clinique, 2013; $\mathrm{N}^{\circ}$ 018; 36-42.

[5] Janky E, Etienne-julan M, Kadhel PH, Leborgne-samuel Y, Melki E. Drépanocytose et Grossesse. Collège National Des Gynécologues et Obstétriciens Français. Tome XXX. Publié au trentième Journées nationales Paris, le 29.11.2006.

[6] Institut National de la Statistique et de l'Analyse Economique (INSAE) et ICFINSAE. Enquête Démographique et de Santé au Bénin (EDSB); 2018 2017-2018: indicateurs Clés. Cotonou, Bénin et Rocville, Maryland, USAINSAE et ICF. P 15-16.

[7] Organisation Mondiale de la Santé. Drépanocytose. Rapport du secrétariat 59è Assemblée mondiale de la santé 2006) Drépanocytose. WHA59/2006/REC/3.
[8] Diallo DA, Guindo A, Touré BA, Sarro YS, Sima M, Tessougué O, Baraika MA, Guindo P, Traoré M, Diallo M, Dorie A. Dépistage néonatal ciblé de la drépanocytose: limites du test de falciformation (test d'Emmel) dans le bilan prénatal ouest africaine. Revue d'Epidémiologie et de Santé Publique xxx (2018) xxx.

[9] Elie Nkwabonga, Pernelle Ngoundjou Dongmob, Claude Tayouc and Theophile Nana Njamend. Outcome of pregnancies among women with sickle cell disease. The journal of maternal-fetal \& neonatal medicine https://doi.org/10.1080/14767058.2020.1743657.

[10] Kelly Kuo, Aaron B Caughey. Contemporary outcomes of sickle cell disease in pregnancy. Am J Obstet Gynecol. 2016 Oct; 215 (4): 505. e1-5. doi: 10.1016/j.ajog.2016.05.032. Epub 2016 May 27.

[11] J. B. Arlet. Avancées thérapeutiques dans la drépanocytose: vers les thérapies ciblées. 2020; 41: 73-77.

[12] Diop S, Mokono S. O, Ndiaye M, Touré Fall A. O, Thiam D, Diakhaté L. La drépanocytose homozygote après l'âge de 20 ans: suivi d'une cohorte de 108 patients au CHU de Dakar. La revue de médecine interne 24 (2003) 711-715.

[13] N. Lélicée, F. Venditteli, S. Ughetto, E. Janky. La qualité du suivi de la grossesse interfère -elle avec les issues de la grossesse, en Guadeloupe? Gynécologie obstétrique et fertilité (41) 2013 282-288.

[14] Chantal Lagresle-Peyrou, François Lefrère, Elisa Magrin, Jean-Antoine Ribeil, Oriana Romano, Leslie Weber, Alessandra Magnani, Hanem Sadek, Clémence Plantier, Aurélie Gabrion, Brigitte Ternaux, Tristan Félix Chloé Couzin, Aurélie Stanislas, Jean-Marc Tréluyer, Lionel Lamhaut, Laure Joseph, Marianne Delville, Annarita Miccio, Isabelle AndréSchmutz Marina Cavazzana. Plerixafor enables safe, rapid, efficient mobilization of hematopoietic stem cells in sickle cell disease patients after exchange transfusion. Haematologica. 2018 May; 103 (5): 778-786. doi: 10.3324/haematol.2017.184788.

[15] Elizabeth Biller, Yong Zhao, Mary Berg, Lisa Boggio, Kelley E Capocelli, Deanna C Fang, Scott Koepsell, Lejla MusicAplenc, Huy P Pham, Angela Treml, John Weiss, Geoffrey Wool, Beverly W Baron. Red blood cell exchange in patients with sickle cell disease-indications and management: a review and consensus report by the therapeutic apheresis subsection of the AABB. Transfusion 2018 Aug; 58 (8): 1965-1972. doi: $10.1111 /$ trf. 14806

[16] Patel S, Purohit, P., Jit, B. P., \& Meher, S. (2019). Pregnancy outcomes in women with sickle cell disease: a retrospective study from Eastern India. Journal of Obstetrics and Gynaecology 2019: $39 \quad$ (6), $382-884$. https://doi.org/10.1080/01443615.2019.1571024.

[17] M. de Montalembert. Pathologies maternelles et grossesse. Drépanocytose et période néonatale. J Gynecol Obstet Biol Reprod 2004; 33 (suppl. au n 1): 1S12-1S14.

[18] Can Boga, Hakan Ozdogu. Pregnancy and sickle cell disease: A review of the current literature. Crit Rev Oncol Hematol2016 Feb; 98: 364-74. doi: 10.1016/j.critrevonc.2015.11.018.

[19] Amanda Redden Hathaway. Sickle Cell Disease in Pregnancy. South Med J 2016 Sep; 109 (9): 554-6. doi: 10.14423/SMJ.0000000000000514. 
[20] Evelyn Bae, Virginia Tangel, Nathan Liu, Sharon E Abramovitz, Robert $\mathrm{S}$ White. Inpatient mortality and postpartum readmission rates in sickle cell disease pregnancies: a multistate analysis, 2007-2014. J Matern Fetal Neonatal Med 2019 Oct 6; 1-10. doi: $10.1080 / 14767058.2019 .1671333$.

[21] N Lesage, C Deneux Tharaux, M Saucedo, A Habibi, F Galacteros, R Girot, M H Bouvier Colle, G Kayem. Maternal mortality among women with sickle-cell disease in France, 1996-2009. Eur J Obstet Gynecol Reprod Biol 2015 Nov; 194: 183-8. doi: 10.1016/j.ejogrb.2015.09.016.

[22] Neeta Natu, Seema Khandelwal, Ravindra Kumar, Anupama Dave. Maternal and perinatal outcome of women with sickle cell disease of a tribal population in Central India. Hemoglobin. 2014; 38 (2): 91-4. doi: $10.3109 / 03630269.2013 .869501$. 